Note

\section{Purification and Properties of meso-Diaminopimelate Dehydrogenase from Brevibacterium sp.}

\author{
Haruo Misono, Masanobu Ogasawara \\ and Susumu NAGASAKI \\ Department of Agricultural Chemistry, \\ Kochi University, Nankoku, \\ Kochi 783, Japan \\ Received November 5, 1985
}

meso-Diaminopimelate dehydrogenase (EC 1.4.1.16) catalyzes the reversible oxidative removal of an amino group with the D-configuration in the substrate in the presence of $\mathrm{NADP}^{+}$to yield L-2-amino-6-ketopimelate. ${ }^{1)}$ The enzyme functions in lysine biosynthesis of Bacillus sphaericus $^{2)}$ and Corynebacterium glutamicum. ${ }^{3)}$ It has been purified to homogeneity from B. sphaericus IFO 3525 and characterized enzymologically. ${ }^{4 \sim 6)}$ The enzyme is used for spectrophotometric measurement of meso-2,6diaminopimelate and for assay of diaminopimelate epimerase $^{7,8)}$ The enzyme is also useful for the preparation and measurement of L-2-amino-6-ketopimelate, ${ }^{2,9)}$ an intermediate in bacterial lysine biosynthesis, and for the preparation of stereospecifically isotope-labeled meso2,6-diaminopimelate. ${ }^{10)}$ We found a high activity of the enzyme in a lysine producer, Brevibacterium sp. ICR 7000, and purified the enzyme to homogeneity from these cells to compare its properties with those of the B. sphaericus enzyme.

We describe here an improved purification procedure and some properties of meso-diaminopimelate dehydrogenase from Brevibacterium sp. ICR 7000.

The dehydrogenase activity was measured at $30^{\circ} \mathrm{C}$ by the rate of increase in the absorbance at $340 \mathrm{~nm}$ with a Hitachi 124 spectrophotometer. The standard reaction mixture consisted of $10 \mu \mathrm{mol}$ meso-2,6-diaminopimelate, $1 \mu \mathrm{mol}$ of $\mathrm{NADP}^{+}, 200 \mu \mathrm{mol}$ of glycine-KCl-KOH buffer (pH 10.5) and enzyme in a final volume of $1.0 \mathrm{ml}$. The assay system for the reductive amination contained $3.65 \mu \mathrm{mol}$ of $\mathrm{L}$-2-amino-6-ketopimelate, $0.2 \mu \mathrm{mol}$ of NADPH, $100 \mu \mathrm{mol}$ of ammonium sulfate, $300 \mu \mathrm{mol}$ of Tris- $\mathrm{HCl}$ buffer $(\mathrm{pH} 7.5)$ and enzyme in a final volume of $1.0 \mathrm{ml}$. L-2-Amino-6-ketopimelate was prepared by oxidation of 2,6-diaminopimelate (a mixture of D, L, and meso) with meso-diaminopimelate dehydrogenase and purified by Dowex $50 \times 8\left(\mathrm{H}^{+}\right)$column chromatography. ${ }^{1)}$ Protein was measured by the procedure of Lowry et al. ${ }^{11)}$ with bovine serum albumin as a standard. One unit of the enzyme was defined as the amount of enzyme that catalyzes the formation of $1 \mu \mathrm{mol}$ of NADPH per min in the oxidative deamination of meso-2,6-diaminopimelate. Specific activity was expressed as units per mg of protein. Brevibacterium sp. ICR 7000 was grown in a medium $(\mathrm{pH}$ 7.2) containing $1.0 \%$ peptone, $0.2 \% \quad \mathrm{~K}_{2} \mathrm{HPO}_{4}, 0.2 \%$ $\mathrm{KH}_{2} \mathrm{PO}_{4}, 0.2 \% \mathrm{NaCl}, 0.01 \% \mathrm{MgSO}_{4} \cdot 5 \mathrm{H}_{2} \mathrm{O}$ and $0.01 \%$ yeast extract. The bacteria were grown aerobically in 2liter flasks containing $500 \mathrm{ml}$ of the medium on a reciprocating shaker at $28^{\circ} \mathrm{C}$ for $48 \mathrm{hr}$. The cells were harvested by centrifugation and washed twice with $0.85 \%$ $\mathrm{NaCl}$. The enzyme was purified at $0 \sim 4^{\circ} \mathrm{C}$ and potassium phosphate buffer ( $\mathrm{pH} 7.4$ ) containing $0.01 \%$ 2-mercaptoethanol was used throughout, unless otherwise specified.

Step 1. The washed cells (about $360 \mathrm{~g}$, wet weight) were disrupted by grinding in a mortar with levigated aluminum oxide and extracted with $0.1 \mathrm{M}$ potassium phosphate buffer ( $\mathrm{pH} 7.2$ ) containing $0.02 \%$ 2-mercaptoethanol. The supernatant solution obtained by centrifugation was dialyzed against $0.01 \mathrm{~m}$ buffer.

Step 2. The dialyzed enzyme solution was brought to $50 \%$ saturation with ammonium sulfate. The $\mathrm{pH}$ was kept at 7.4 by addition of $14 \%$ ammonium hydroxide solution during the ammonium sulfate fractionation. The precipitate was removed by centrifugation and ammonium sulfate was added to the supernatant solution to $80 \%$ saturation. The precipitate was collected, dissolved in $0.01 \mathrm{M}$ buffer, and dialyzed against $0.01 \mathrm{M}$ buffer.

Step. 3. The enzyme solution was put on a DEAEcellulose column $(4.5 \times 45 \mathrm{~cm})$ equilibrated with $0.01 \mathrm{M}$ buffer. After the column was washed with the buffer containing $0.1 \mathrm{M} \mathrm{NaCl}$, the enzyme was eluted with the buffer supplemented with $0.2 \mathrm{M} \mathrm{NaCl}$. The active fractions were combined and concentrated with an Amicon membrane filter PM-10.

Step 4. The enzyme solution was placed on a hydroxyapatite column $(3.2 \times 15 \mathrm{~cm})$ equilibrated with $0.01 \mathrm{M}$ buffer. The column was washed with the same buffer and the enzyme was eluted with $0.03 \mathrm{~m}$ buffer. The active fractions were combined and concentrated with an Amicon membrane filter PM-10.

Step 5. The enzyme solution was then put on a $2^{\prime}, 5^{\prime}$ ADP-Sepharose 4B column $(1.2 \times 7.0 \mathrm{~cm})$ equilibrated with $0.1 \mathrm{M}$ potassium phosphate buffer $(\mathrm{pH} 7.2)$ containing $0.01 \% 2$-mercaptoethanol. After the column was washed with the same buffer, the enzyme was eluted with the buffer containing $0.3 \mathrm{M} \mathrm{KCl}$. The active fractions were concentrated with an Amicon membrane filter PM-10 and stored at $-20^{\circ} \mathrm{C}$ in the presence of $10 \%$ glycerol until use. Approximately 380 -fold purification was achieved with an overall yield of $23 \%$. A summary of the purification procedure is presented in Table I.

The purified enzyme showed a single band upon disc gel electrophoresis and sodium dodecyl sulfate-disc gel electrophoresis. The molecular weight of the enzyme was approximately 70,000 by the Sephadex G-150 gel filtration method of Andrews. ${ }^{12}$ ) The molecular weight of the 
Table I. Purification of meso-Diaminopimelate Dehydrogenase FROM Brevibacterium sp. ICR 7000

\begin{tabular}{lccccc}
\hline \multicolumn{1}{c}{ Step } & $\begin{array}{c}\text { Total } \\
\text { protein } \\
(\mathrm{mg})\end{array}$ & $\begin{array}{c}\text { Specific } \\
\text { activity } \\
\text { (units/mg) }\end{array}$ & $\begin{array}{c}\text { Total } \\
\text { units }\end{array}$ & $\begin{array}{c}\text { Yield } \\
(\%)\end{array}$ & Purification \\
\hline Crude extract & 7,480 & 0.348 & 2,600 & 100 & 1 \\
Ammonium sulfate & 3,400 & 0.623 & 2,120 & 81.5 & 1.8 \\
$\quad$ fractionation & 481 & 3.98 & 1,910 & 73.5 & 11.4 \\
DEAE-cellulose & 175 & 6.29 & 1,100 & 42.3 & 18.1 \\
Hydroxyapatite & 4.74 & 131.0 & 621 & 23.9 & 376 \\
2',5'-ADP-Sepharose 4B $^{\prime}$ & & & & \\
\hline
\end{tabular}

subunits was about 39,000 by sodium dodecyl sulfate-disc gel electrophoresis by the method of Weber and Osborn. ${ }^{13)}$ These results suggest that the enzyme is composed of two subunits identical in molecular weight, although the discrepancy between the values of molecular weight thus obtained has not been elucidated. The isoelectric point of the enzyme was 5.0 by isoelectric focusing on a polyacrylamide gel. ${ }^{14)}$

The enzyme was stable up to $48^{\circ} \mathrm{C}$ when incubated for $10 \mathrm{~min}$ in $0.01 \mathrm{M}$ potassium phosphate buffer $(\mathrm{pH} 7.4)$. The enzyme was stable, when incubated at $40^{\circ} \mathrm{C}$ for $10 \mathrm{~min}$, over the $\mathrm{pH}$ range 7.0 to 9.0 . The enzyme had its maximal reactivity at about $\mathrm{pH} 10.5$ for the oxidative deamination of meso-2,6-diaminopimelate and at $\mathrm{pH} 8.5$ for the reductive amination of L-2-amino-6-ketopimelate. The enzyme deaminated exclusively the meso form of 2,6-diaminopimelate; neither the D nor L-isomer served as a substrate. L-Glutamate, L-alanine, L-leucine, L-valine, and L-lysine were inert as substrates for the enzyme. Ishino et $a l .^{3)}$ reported that the partially purified enzyme from $C$. glutamicum uses $\mathrm{NAD}^{+}$in addition to $\mathrm{NADP}^{+}$ as a coenzyme, though the relative rate was not shown. We investigated the reactivity of $\mathrm{NAD}^{+}$with the Brevibacterium enzyme. $\mathrm{NAD}^{+}$served as a coenzyme at $3 \%$ of the rate of $\mathrm{NADP}^{+}$at the concentration of $1 \mathrm{~mm}$. The enzyme was inhibited by iodoacetic acid $(55 \%$ inhibition at $1 \mathrm{~mm}), \quad N$-ethylmaleimide $(52 \% ; 1 \mathrm{mM}), \quad \mathrm{HgCl}_{2}$ $(100 \%, 0.01 \mathrm{~mm}), \mathrm{CuSO}_{4} \cdot 5 \mathrm{H}_{2} \mathrm{O}(68 \%, 0.01 \mathrm{~mm})$, and $\mathrm{NiSO}_{4}(21 \%, 1 \mathrm{~mm})$. The enzyme activity was little affected by $1 \mathrm{~mm}$ EDTA, $\alpha, \alpha^{\prime}$-dipyridyl, $\mathrm{NaN}_{3}, \mathrm{KCN}$, or sodium arsenate.

The enzyme also might function in the lysine biosynthesis of this bacterium as shown in C. glutamicum $^{3)}$ and $B$. sphaericus. ${ }^{2)}$ L-Lysine (10 mM), however, did not inhibit the enzyme. The enzyme is similar to the $B$. sphaericus enzyme in this respect. ${ }^{5}$ )

The Michaelis constants for meso-2,6-diaminopimelate and $\mathrm{NADP}^{+}$were 6.25 and $0.14 \mathrm{~mm}$, respectively, at $\mathrm{pH}$ 10.5 by the procedure described in our previous paper. ${ }^{5)}$ The $K m$ values for NADPH, L-2-amino-6-ketopimelate, and ammonia were $0.23,0.21$ and $62.5 \mathrm{~mm}$, respectively, at $\mathrm{pH}$ 7.5. The $K m$ value for $\mathrm{NAD}^{+}$was $2.0 \mathrm{~mm}$ by
Lineweaver-Burk plots with the reaction system ( $\mathrm{pH} 10.5)$ containing $10 \mathrm{~mm}$ meso-2,6-diaminopimelate.

The properties of this enzyme are similar to those of the B. sphaericus enzyme. ${ }^{4,5)}$ However, the $\mathrm{pH}$ optimum for the reductive amination of L-2-amino-6-ketopimelate, the $\mathrm{Km}$ value for ammonia, and the reactivity of $\mathrm{NAD}^{+}$are different in the enzymes from Brevibacterium sp. and $B$. sphaericus.

Acknowledgment. The authors thank Dr. K. Soda, Kyoto University, Japan, for his helpful discussions.

\section{REFERENCES}

1) H. Misono, H. Togawa, T. Yamamoto and K. Soda, J. Bacteriol., 137, 22 (1979).

2) P. J. White, J. Gen. Microbiol., 129, 739 (1983).

3) S. Ishino, K. Yamaguchi, S. Shirahata and K. Araki, Agric. Biol. Chem., 48, 2557 (1984).

4) H. Misono and K. Soda, Agric. Biol. Chem., 44, 227 (1980).

5) H. Misono and K. Soda, J. Biol. Chem., 255, 10599 (1980).

6) H. Misono, S. Nagasaki and K. Soda, Agric. Biol. Chem., 45, 1455 (1981).

7) H. Misono and K. Soda, Agric. Biol. Chem., 44, 2125 (1980).

8) J. S. Wiseman and J. S. Nichols, J. Biol. Chem., 259, 8907 (1984).

9) S. A. Simms, W. H. Voige and C. Gilvarg, J. Biol. Chem., 259, 2734 (1984).

10) K. Tanizawa, T. Yoshimura, Y. Asada, S. Sawada, H. Misono and K. Soda, Biochemistry, 21, 1104 (1982).

11) O. H. Lowry, N. J. Rosebrough, A. L. Farr and R. J. Randall, J. Biol. Chem., 193, 265 (1951).

12) P. Andrews, Biochem. J., 96, 595 (1965).

13) K. Weber and M. Osborn, J. Biol. Chem., 244, 4406 (1969).

14) P. Righetti and J. W. Drysdale, Biochim. Biophys. Acta, 236, 17 (1971).

15) B. J. Davis, Ann. N. Y. Acad. Sci., 121404 (1964). 